\title{
Recurrent Priapism Related with Low Single Dose Olanzapine

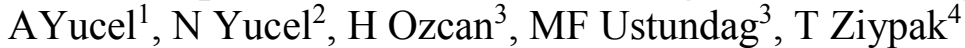

\begin{abstract}
Priapism is defined as persistent prolonged erection of the penis, usually painful, without sexual arousal or desire, generally continuing for hours. Many medical situations and drugs, especially psychotropic agents, may cause priapism. The mechanism of psychotropic druginduced priapism is not fully known, but $\alpha 1$ - adrenergic receptor blockade in the corpus cavernous is being accused. Priapism is an urgent situation for the health of the patient. Cavernous old blood is drained by a butterfly needle or a diluted solution of an alphaadrenergic agonist is injected into the corporal space. In the event failure of medical treatment, surgical interference may be needed to avert fibrosis and impotence due to tissue death. For preventing that condition, a fistula between the deep dorsal vein or saphenous vein and the glans penis, the corpus cavernosum, and corpus spongiosum is constituted to open a new way for the venous circulation.
\end{abstract}

Keywords: Olanzapine, Priapism, Recurrence

From: ${ }^{1}$ Department of Psychiatry, Erzurum Regional Education and Research Hospital, Erzurum, ${ }^{2}$ Departments of Child and Adolescent Psychiatry, ${ }^{3}$ Department of Psychiatry, ${ }^{4}$ Departments of Urology, Faculty of Medicine, Ataturk University, Erzurum, Turkey.

Correspondence: Dr N Yucel, Department of Child and Adolescent Psychiatry, Faculty of Medicine, Ataturk University, Erzurum 25040, Turkey. Fax: +90 442344 6528, e-mail: md.nerminyucel@gmail.com 


\section{INTRODUCTION}

Priapism is a permanent and usually painful penile erection, lasting approximately 4 hours, frequently having no relation to sexual stimuli. Drug onset is the one of the most common reasons, being the cause of priapism in $25-40 \%$ of cases. Various groups of medications are included, such as antidepressants, antipsychotics, antihypertensive, anticoagulants, alphablockers, and some psychoactive substances (1). In this report, we present a case with olanzapine-induced priapism in order to draw the attention of clinicians to this rare side effect.

\section{CASE REPORT}

A 24-year-old male with schizoaffective disorder checked into our outpatient clinic with his parents. He had been using quetiapine $600 \mathrm{mg}$ /day for over two years. He declared that he had stopped using quetiapine for the last three months because it slowed down his his movements, and thought that his present clinical condition was good. However his parents complained that his usage of quetiapine was irregular and that he suffered from insomnia and nervousness, talked to himself and thought that people talked about him. Moreover, he experienced increasing on amount of speech, laughing and movements. During his psychiatric examination, the patient was conscious and his orientation relating to people, place, and time was completely normal. His immediate, recent, and remote memory and mental capacity were also normal. Affect and mood were irritable, while increased selfesteem was observed. The content of his thoughts involved reference and persecutory delusions. The need for sleep decreased in the last month, and hallucination was not reported by him or his parents. Laboratory examinations were normal. The patient also insisted on not using quetiapine, and then olanzapine $10 \mathrm{mg} /$ day was initiated. Priapism occurred in the $6^{\text {th }}$ 
hour of first dosage. He consulted with the urology department, and the corpus cavernosum was then drained in accordance with the consultation. Olanzapine $2.5 \mathrm{mg}$ was initiated the following day, and also the dose was set to increase slowly. However the priapism occurred again. The drainage of the corpus cavernosum was repeated and then the erection was ended; shunt was not required. Finally, olanzapine was stopped and risperidone $2 \mathrm{mg} /$ day was initiated - this is the $5^{\text {th }}$ week of patient follow-up with risperidone. The priapism has not occurred again, and affective and psychotic symptoms have decreased.

\section{DISCUSSION}

Priapism is an urgent situation that requires intervention via drainage of the corpus cavernosum and using an alpha adrenergic agonist. Additionally, some patients who do not respond to drainage of the corpus cavernosum may require shunt surgery (2). The reason for drug-induced priapism is still completely unknown, but alpha-1 adrenergic receptor blockade in the corpus cavernosum of the penis is suspected (3). In the literature, olanzapine-induced priapism was reported as occurring olanzapine with low and high dosage, single and multiple medications, as well as short-term and long-term uses (4-19). Contrary to others, priapism was observed with single-dose olanzapine in our case; furthermore, priapism occurred with repeated low doses of olanzapine. Quetiapine might cause priapism by itself $(19,20)$. Another interesting aspect of our case is that the priapism did not occur due to usage of quetiapine during the two-year period, although the $600 \mathrm{mg} /$ day dose of quetiapine is considerably higher than the equivalent dose of olanzapine $2.5 \mathrm{mg} /$ day. Furthermore, olanzapine and quetiapine are second-generation antipsychotics. They also affect similar receptors but their complex pharmacokinetic and pharmacodynamics profiles and binding potentials on alpha-1 adrenergic receptors might be different. These differences might explain 
why in our case priapism occurred with olanzapine and without quetiapine. Priapism is a rare idiosyncratic side effect of antipsychotics. Finally, we concluded that medications with weak alpha-1 adrenergic blockage must be used in the treatment of priapism.

* The authors declare that there are no conflicts of interest. 


\section{REFERENCES}

1. Doufik J, Otheman Y, Khalili L, Ghanmi J, Ouanass A. [Antipsychotic-induced priapism and management challenges: A case report.]. Encephale 2014.

2. Mains E, Aboumarzouk O, Ahmad S, El-Mokadem I, Nabi G. A minimally invasive temporary cavernoso-saphenous shunt in the management of priapism after failed conservative treatment. Minim Invasive Ther Allied Technol 2012; 21: 366-8.

3. Andersohn F, Schmedt N, Weinmann S, Willich SN, Garbe E. Priapism associated with antipsychotics: role of alpha1 adrenoceptor affinity. J Clin Psychopharmacol 2010; 30: 68-71.

4. Shahani L. Olanzapine-associated priapism. J Neuropsychiatry Clin Neurosci 2012; 24: E28.

5. Hosseini SH, Polonowita AK. Priapism associated with olanzapine. Pak J Biol Sci 2009; 12: 198-200.

6. Childers JB, Schwartz AC, Compton MT. Olanzapine-associated priapism. Psychosomatics 2003; 44: 351-2.

7. Songer DA, Barclay JC. Olanzapine-induced priapism. Am J Psychiatry 2001; 158: 2087-8.

8. Kuperman JR, Asher I, Modai I. Olanzapine-associated priapism. J Clin Psychopharmacol 2001; 21: 247.

9. Deirmenjian JM, Erhart SM, Wirshing DA, Spellberg BJ, Wirshing WC. Olanzapineinduced reversible priaprism: a case report. J Clin Psychopharmacol 1998; 18: 351-3.

10. Gordon M, de Groot CM. Olanzapine-associated priapism. J Clin Psychopharmacol 1999; 19: 192.

11. Heckers S, Anick D, Boverman JF, Stern TA. Priapism following olanzapine administration in a patient with multiple sclerosis. Psychosomatics 1998; 39: 288-90. 
12. Penaskovic KM, Haq F, Raza S. Priapism during treatment with olanzapine, quetiapine, and risperidone in a patient with schizophrenia: a case report. Prim Care Companion J Clin Psychiatry 2010; 12.

13. Jagadheesan K, Thakur A, Akhtar S. Irreversible priapism during olanzapine and lithium therapy. Aust N Z J Psychiatry 2004; 38: 381.

14. Matthews SC, Dimsdale JE. Priapism after a suicide attempt by ingestion of olanzapine and gabapentin. Psychosomatics 2001; 42: 280-1.

15. Compton MT, Saldivia A, Berry SA. Recurrent priapism during treatment with clozapine and olanzapine. Am J Psychiatry 2000; 157: 659.

16. Reeves RR, Mack JE. Priapism associated with two atypical antipsychotic agents. Pharmacotherapy 2002; 22: 1070-3.

17. Compton MT, Miller AH. Priapism associated with conventional and atypical antipsychotic medications: a review. J Clin Psychiatry 2001; 62: 362-6.

18. Seger A, Lamberti JS. Priapism associated with polypharmacy. J Clin Psychiatry 2001; 62: 128.

19. Torun F, Yilmaz E, Gumus E. Priapism due to a single dose of quetiapine: a case report. Turk Psikiyatri Derg 2011; 22: 195-9.

20. Ozkaya F, Ziypak T, Adanur S, Yucel A, Aydinoglu U. The Occurrence of Priapism as a Result of the Use of a Single Dose of Quetiapine. . The Eurosian Journal of Medicine (EAJM) 2012; 44: 122-3. 